\title{
A Different Path to the Same Old Question: Why Should Cartels be Criminalised?*
}

\author{
Nuno Castro Marques ${ }^{\star *}$
}

\begin{abstract}
Regardless of the extreme negative qualifications usually attributed to cartels and bid rigging, EU and Portuguese competition laws do not set them apart from other anticompetitive practices regarding the possible applicable sanctions. EU and Portuguese competition laws establish the same potential sanctions for all competition infringements. Despite that, there are clear indications that EU and Portuguese legislators intend to treat cartels differently from all other competition infringements, but those differences have essentially to do with rules or procedures designed to facilitate their detection, production of evidence and decision-making.

Notwithstanding the relevance of the "traditional" arguments regarding cartel criminalisation, we consider that the discussion is still incomplete and would benefit from the inclusion of an additional "filter". As it is a discussion about a criminalisation process, the use of common instruments in criminology can shed more light into the question, and one of those instruments - or the most important one - is the analysis of the legal interests protected by the norm. We deem it essential to think about what legal interests are harmed in each of the different types of competition infringements, so as to conclude if indeed and to what extent cartels and bid rigging are capable of impairing more or different legal interests, or in a different intensity, than those potentially violated by other types of competition infringements.

The conclusion is that cartel and bid rigging conducts always infringe the entire set of legal interests that is or may be defended by competition laws and always do so with high intensity.
\end{abstract}

KEYWORDS: cartels, competition law, objectives of competition law, legal interests

\footnotetext{
* Date of reception: 23 August 2017. Date of acceptance: 05 September 2017.

** Assistant Professor, School of Economics and Management of Universidade do Porto, 4200-464 Porto, Portugal.nmarques@fep.up.pt.
} 


\section{Introduction}

It is becoming more common to consider that "cartel activity is unique in competition law"1 and an increasing consensus condemning cartels as the worst anticompetitive practice can even be found namely at an international level, with the Organisation for Economic Co-operation and Development (OECD) considering already for some time that "[...] hard core cartels are the most egregious violations of competition law [...]". ${ }^{2}$ Also the International Competition Network (ICN) recognises a "worldwide consensus $[\ldots]$ on the recognition that hard core cartels harm consumers and damage economies", ${ }^{3}$ and States are more and more receptive to engage in international cooperation on antitrust enforcement with the objective of an effective punishment of cartel members. ${ }^{4}$

In the legal scholarship we find severe expressions for cartel qualification, such as "anathema to competitive markets", 5 "primary evil of global trade", 6 "economically detrimental to society [...] morally wrong, and [...] morally equivalent to other kinds of behaviour that are generally considered to be criminal in nature", 7 or even "cancers on the open market economy" and "supreme evil of antitrust", 8 "social evils which must

\footnotetext{
${ }^{1}$ Gregory J. Werden, "Sanctioning Cartel Activity: Let the Punishment Fit the Crime", European Competition Journal 5, no. 1 (2009): 25.

${ }^{2}$ OCDE, "Recommendation of the Council Concerning Effective Action against Hard Core Cartels" (Paris: OCDE, 1998), 2.

${ }^{3}$ ICN, "Defining Hard Core Cartel Conduct" (Luxembourg: ICN, 2005), 5.

${ }^{4}$ For the analysis of the increasing international cooperation in the field of antitrust enforcement, see Julian M. Joshua, Peter D. Camesasca, and Youngjin Jung, "Extradition and Mutual Legal Assistance Treaties: Cartel Enforcement's Global Reach", Antitrust Law Journal 75, no. 2 (2008): 353-397; Michael O'Kane, "Does Prison Work for Cartelists? The View from Behind Bars: An Interview of Bryan Allison", Antitrust Bulletin 56, no. 2 (2011): 483-500; Frank R. Schoneveld, "Cartel Sanctions and International Competition Policy: Cross-Border Cooperation and Appropriate Forums for Cooperation”, World Economy 26, no. 3 (2003): 433-471; A. Paul Victor, "The Growth of International Criminal Antitrust Enforcement", George Mason Law Review 6, no. 3 (1998): 493-503; and Cynthia Day Wallace, “'Extraterritorial' Discovery: Ongoing Challenges for Antitrust Litigation in an Environment of Global Investment", Journal of International Economic Law 5, no. 2 (2002): 353-392.

${ }^{5}$ Caron Beaton-Wells and Christine Parker, "Justifying Criminal Sanctions for Cartel Conduct: A Hard Case", Journal of Antitrust Enforcement 1, no. 1 (2013): 198.

${ }^{6}$ Michal S. Gal, "Free Movement of Judgments: Increasing Deterrence of International Cartels through Jurisdictional Reliance”, Virginia Journal of International Law 51, no. 1 (2010): 58.

${ }^{7}$ Anthony Gray, "Criminal Sanctions for Cartel Behaviour", Queensland University of Technology Law and Justice Journal 8, no. 2 (2008): 378.

${ }^{8}$ Christopher Harding, "Cartel Deterrence: The Search for Evidence and Argument", Antitrust Bulletin 56, no. 2 (2011): 347.
} 
be destroyed", " that "have no legitimate purposes and serve only to rob consumers of the tangible blessings of competition", ${ }^{10}$ being "the most damaging type of anti-competitive practice', against which 'a zero tolerance policy' is justified, requiring 'all measures to stamp them out'". ${ }^{11}$

Also the Court of Justice of the European Union (ECJ) accepts that cartels featuring "restrictions on prices, market-sharing and concerted measures against competitors rank amongst the most serious interferences with freedom of competition".12 This is followed by the Portuguese Courts that also consider price fixing and client sharing cartels as the "most serious and classic infringement of competition law"."13

Despite these quite extreme qualifications of cartels, EU and Portuguese competition laws established the same potential sanction for all competition infringements: a fine up to $10 \%$ of the involved undertaking turnovers, notwithstanding infringement is a hard-core cartel, any other type of horizontal agreement, a vertical agreement, an abuse of dominant position or even, in what concerns the specific situation of the Portuguese competition law, an abuse of economic dependence. ${ }^{14}$ That finding does not change if we also consider the object of the infringement, as the potential sanction is always the same regardless of the type of the competition infringement e.g. related to confidential information sharing, price fixing, market and/ or client sharing, or even a collusion in public tenders (bid rigging). And specifically concerning the Portuguese competition law that also establishes the possibility of personal sanctions for board members or directors directly involved in the undertaking infringements, the same applies as the maximum potential fine is up to $10 \%$ of their annual remuneration regardless of the infringement type (cartel, vertical agreement, and abuse of dominant position or abuse of economic dependence). ${ }^{15}$

\footnotetext{
${ }^{9}$ Fritz E. Koch, "Cartels as Instruments of International Economic Organisation. Public and Private Legal Aspects of International Cartels", Modern Law Review 8, no. 3 (1945): 130.

${ }^{10}$ Gregory J. Werden, Scott D. Hammond, and Belinda A. Barnett, "Deterrence and Detection of Cartels: Using All the Tools and Sanctions", Antitrust Bulletin 56, no. 2 (2011): 208-209.

${ }^{11}$ Maarten Pieter Schinkel, "Effective Cartel Enforcement in Europe", World Competition 30, no. 4 (2007): 539.

${ }^{12}$ Judgment of 11 March 1989, SC Belasco, C-246/86, EU:C:1989:301, paragraph 66.

${ }^{13}$ Judgment of the Tribunal da Concorrência, Regulação e Supervisão of 7 March 2014, Contiforme - Soluções Gráficas Integradas, S.A., proc. 38/13.8YUSTR, 143-144.

${ }^{14}$ See Article 23(2) of Regulation 1/2003 and Articles 68(1) and 69(2) of the Portuguese Competition Act (Lei 19/2012).

${ }^{15}$ Article 69(4) of the Portuguese Competition Act.
} 
Nevertheless, there are clear indications that EU and Portuguese legislators intend to treat cartels differently from all other competition infringements. As for EU competition law, the leniency regime ${ }^{16}$ and the settlement procedure ${ }^{17}$ apply exclusively to cartel cases and are justified by the consideration that "Cartels are [...] among the most serious violations of Article [101]", ${ }^{18}$ and also the private enforcement directive recently brought the innovation of establishing a iuris tantum presumption that "cartel infringements cause harm". ${ }^{19}$ The Portuguese competition law presents an almost similar situation, with its leniency programme exclusively applicable to cartel cases ${ }^{20}$ whilst the transaction procedure is applicable also to other competition infringements. ${ }^{21}$

Nonetheless, what EU and Portuguese competition laws established differently in relation to cartels has essentially to do with rules or procedures designed to facilitate their detection, production of evidence and decision-making.

\section{Traditional arguments relating to cartel criminalisation}

Notwithstanding the possibility for the European Commission or the Portuguese Competition Authority to differentiate cartels from other competition infringements, in particular by imposing within the limits of the sanctioning framework higher sanctions in concrete decisions motivated by the special gravity of the cartels, ${ }^{22}$ we do not consider it a fully coherent solution with the assessment that is made transversally regarding the highly objectionable and harmful features of cartels, and all the more when those characteristics are precisely used to justify cartel leniency pro-

\footnotetext{
${ }^{16}$ See the Commission Notice on Immunity from fines and reduction of fines in cartel cases (2006/ C298/11), Official Journal of the European Union C 298/17.

${ }^{17}$ See the Commission Notice on the conduct of settlement procedures in view of the adoption of Decisions pursuant to Article 7 and Article 23 of Council Regulation (EC) no. 1/2003 in cartel cases (2008/C167/01), Official Journal of the European Union C 167/1.

${ }^{18}$ See paragraph 1 of the Commission Notice on Immunity from fines and reduction of fines in cartel cases.

${ }^{19}$ Article 17(2) of the Directive 2014/104/EU of the European Parliament and of the Council of 26 November 2014 on certain rules governing actions for damages under national law for infringements of the competition law provisions of the Member States and of the European Union, Official Journal of the European Union L 349/1.

${ }^{20}$ Article 75 of the Portuguese Competition Act.

${ }^{21}$ Articles 22 and 27 of the Portuguese Competition Act.

${ }^{22}$ See e.g. paragraphs 28 and 29 of the Guidelines on the method of setting fines imposed pursuant to Article 23(2)(a) of Regulation no. 1/2003, OJ C 210, 1.9.2006, 2-5.
} 
grammes, surpassing moral reservations that arise when granting sanction immunity to an infringer in exchange of its cooperation to denounce the other co-infringers. ${ }^{23}$

The recurrent arguments for and against cartel criminalisation must be considered, as they are explicitly or implicitly based on a different consideration of cartels in relation to other competition infringements. Nevertheless and as WHELAN rightly points out, "It is sometimes claimed, for example, that cartel activity should be criminalised because it is 'wrong', but more often than not, such statements are not followed by rigorous analysis of the application of criminal punishment theory to the specific case of cartel activity". ${ }^{24}$

Taking the example of Australia that recently opted for the criminalisation of the cartel conduct and following an extensive public debate led by its competition authority - the Australian Competition \& Consumer Commission -, the arguments presented for the criminalisation were based on the assumption of the negative impact of cartels on economic and consumer welfare, but also on the moral wrongdoing of the conduct, defended as similar to theft, fraud, insider trading, market manipulation, and other white collar crimes, and the insufficient dissuasive effect of pecuniary sanctions, as the secrecy of cartels and the difficulty of its detection and punishment would set the optimal level of fines - i.e. suitable to eliminate the illicit gains - so high they would pose a serious risk of bankruptcy for the undertakings concerned, with such a risk inevitably being passed on to innocent parties such as workers, creditors, etc., and thus criminal sanctions were seen as more effective and fair to effectively deter cartels. ${ }^{25}$ Although there are some reservations on the soundness of certain arguments, namely those relating to the deterrence and operational and reputational risks pointed to a process of criminalisation, ${ }^{26}$ the

\footnotetext{
${ }^{23}$ See Wouter P. J. Wils, "Leniency in Antitrust Enforcement: Theory and Practice", World Competition 30, no. 1 (2007): 49-51, on the "negative moral effects" of leniency programmes.

${ }^{24}$ Peter Whelan, The Criminalisation of European Cartel Enforcement - Teoretical, Legal, and Practical Challenges, ed. Paul Craig and Gráinne de Búrca, Oxford Studies in European Law (NY: Oxford University Press, 2014): 7.

${ }^{25}$ See Caron Beaton-Wells, "Criminalising Cartels: Australia's Slow Conversion", World Competition 31, no. 2 (2008): 212-213, and Brenda Marshall, "Criminalisation of Cartel Conduct: Compelling Compliance with Anti-Collusion Laws", Journal of the Australasian Law Teachers Association, no. 3 (2010): 11-13.

${ }^{26}$ See Caron Beaton-Wells and Christine Parker, "Justifying Criminal Sanctions for Cartel Conduct: A Hard Case", Journal of Antitrust Enforcement (2012): 18-19.
} 
arguments in favour were upheld and cartels are now criminally punished in Australia since 2009.

Greece is another example of a recent criminalisation process, in 2009, mainly motivated by the assumption of the well-founded argument of higher deterrence effect of criminal sanctions. Nevertheless, it is also an example of the risk of having an inverse result when enforcement is low, with BRISIMI \& IOANNIDOU referring that "[...t]he scarcity of public criminal enforcement record raises concerns [...] therefore, the marginal deterrence is close to zero accordingly" ${ }^{27} 28$

It is noteworthy that risk of enforcement difficulties arising from a criminalisation process is recurrently highlighted in order to defend the maintenance of non-criminal procedures. Nevertheless, we tend to agree with RILEY when he criticises the EU competition enforcement procedures under the light of the European Convention on Human Rights (ECHR) principles: "[...] one of the principal justifications [...] is that minor offences [...] could be dealt with by a non-art.6 compliant tribunal in order to give the state some flexibility in dealing with large number of minor cases. With a backlog of around 60 cases and handing down no more than eight decisions a year it is difficult to see again how this policy, which underlies the "minor offences" criteria, applies to cartels" ${ }^{29}$

Moreover, the question of a negative impact on deterrence arising from a law weak enforcement is not exclusive of cartels or competition law, but a situation that occurs transversely on the entire spectre of law enforcement. ${ }^{30}$

On an entirely different perspective, we can bring the Canadian example as one of the legal systems that traditionally dealt with competition infringements through criminal sanctions. Indeed the Canadian starting point was that all infringements established in the Combines Investigation

\footnotetext{
${ }^{27}$ Vasiliki Brisimi and Maria Ioannidou, "Criminalizing Cartels in Greece: A Tale of Hasty Developments and Shaky Grounds", World Competition 34, no. 1 (2011): 161-162.

${ }^{28}$ Nevertheless we can find examples of different outcomes of effective deterrence, as referred by Kai Hüschelrath, Nina Leheyda, and Patrick Beschorner, "The Deterrent Effect of Antitrust Sanctions: Evidence from Switzerland", Antitrust Bulletin 56, no. 2 (2011): 428-429, concerning the Swiss situation where evidence was found of cartel dismantling on the immediate day before entering into force an amendment to the Kartellgesetz that substantially increased the sanctions for cartel infringements.

${ }^{29}$ Alan Riley, "The Modernisation of EU Anti-Cartel Enforcement: Will the Commission Grasp the Opportunity?", European Competition Law Review 31, no. 5 (2010): 199.

${ }^{30}$ João Baptista Machado, Introdução ao Direito e ao Discurso Legitimador (1986. Reprint, Coimbra: Almedina, 2016): 36.
} 
Act were of criminal nature, and a first amendment was made in 1976 to start including civil sanctions also. ${ }^{31}$ In 1986, another amendment replaced the criminal sanction for the monopolisation infringement by a civil sanction, and nowadays the only conducts that are still considered as criminal infringements in the actual Competition Act are cartels and bid rigging with imprisonment sanction up to 14 years. ${ }^{32} 33$

In the middle ground we find some relevant legal systems, such as France and Germany, which have maintained a discreet but stable option by treating differently cartels and especially bid rigging as criminal conducts by comparison with others competition infringements.

As to the first, cartels have been considered of criminal nature since the ancient Article 419 of the Code pénal, and that same nature is actually maintained in Article L420-6 of the Code de commerce. It is important to stress that this Article demands three cumulative elements for its application: "The involvement of the individual concerned must be (i) personal in the accomplishment of the competition infringement, as well as (ii) decisive and (iii) fraudulent", ${ }^{4}$ and so its application occurs separately from the undertakings' monetary sanctions applicable by the Autorité de la concurrence. Despite that, over the years enforcement shows an increase on the effective sanctions that have been applied, with VIRos considering that the numbers of convictions are no longer insignificant, as for the past twenty years there was an average of two convictions per year, mainly with

${ }^{31}$ Without prejudice of the correct criticism pointed out by Harry First, "The Case for Antitrust Civil Penalties", Antitrust Law Journal 76, no. 1 (2009): 130-131, about "The lack of clarity as to why some monetary penalties are called 'civil' and why some are called 'criminal' has exasperated many commentators, for the difference in taxonomy is consequential. Once labelled civil, many of the protections available for criminal prosecutions arguably vanish".

${ }^{32}$ See sections 45(1) and 47 of the Canadian Competition Act.

${ }^{33}$ Paul Collins and Vicky Eatrides, "An Analysis of the Proposal to Decriminalise the AntiCompetitive Pricing Practices under the Competition Act", World Competition 26, no. 3 (2003): 391, and Gavin Murphy, "Fine and Prohibition Order in Canadian Bid-Rigging Case Involving Government Contracts", European Competition Law Review 31, no. 1 (2010): 21-24.

${ }^{34}$ David Viros, "Individual Criminal Sanctions in France - Individual Sanctions for Competition Law Infringements: Pros, Cons and Challenges", Concurrences, Revue des Droits de la Concurrence 2-2016 (2016): 25. https://papers.ssrn.com/sol3/papers2.cfm?abstract_id=2782090. For a further analysis of the French framework, also defending that the elements required by Article art. L420-6 should be reviewed in order to facilitate its effective and broader application, see Frédéric Jenny, "Larticulation des Sanctions en Matière de Droit de la Concurrence du Point de Vue Économique - Colloque Les Sanctions du Droit de la Concurrence", 1-2013 (2013): 9, and Jean-Bernard Blaise, "La Sanction Pénale - Colloque Les Sanctions du Droit de la Concurrence", Concurrences, Revue des Droits de la Concurrence 1-2013 (2013): 23-26. 
application of criminal fines, and in five situations effective up to a year jail sanctions were applied. ${ }^{35}$

The German example is even more expressive in what concerns stability and effective application of criminal sanctions to certain competition infringements, even though in this case Article 298 of the Strafgesetzbuch is only applicable to bid rigging, punishable with up to five years of imprisonment. As in the French case, the application of the criminal sanction to individuals occurs separately from the undertakings' monetary sanctions applicable by the Bundeskartellamt, and presents a very relevant activity as, within the period of 2003-2012, between 42 and 230 criminal investigations were opened per year, and in the period of 2008-2012, 20, 19, 17, 20 and 22 cases with convictions were successfully concluded in each of those years, with application of jails sentences in five situations in 2008, three in 2009, one in 2010 and seven in 2011. ${ }^{36}$

That is why PAPP considers that besides the British and Irish experiences in cartel criminalisation, the French and especially the German examples should be highlighted when discussing the option and model for that criminalisation, proving its possible stability and viability in a European context. ${ }^{37}$ In his appreciation of the arguments in favour of cartel criminalisation - considering the traditional arguments such as the insufficient deterrence effect of exclusive monetary sanctions and the reinforcement of the leniency programme when coupled with immunity of criminal sanctions -, he aggregates the critics of criminalisation into two "broad categories" which he designates as "the moral argument" and "the utilitarian argument". The first relates to the discussion that competition law infringements may not be sufficiently "immoral" to justify criminal enforcement and the second is the recurrent fear that criminal enforcement may risk effectiveness of the enforcement. As for the moral argument, we agree with

\footnotetext{
${ }^{35}$ Viros, "Individual Criminal Sanctions": 25-26.

${ }^{36}$ Daniel Zimmer, "Individual Sanctions in German Competition Law: The Case for a Criminalisation of Antitrust Offences? - Individual Sanctions for Competition Law Infringements: Pros, Cons and Challenges", Concurrences, Revue des Droits de la Concurrence 2-2016 (2016): 29. https://papers.ssrn.com/sol3/papers2.cfm?abstract_id=2782090.

${ }^{37}$ Florian Wagner-Von Papp, "Introduction - Individual Sanctions for Competition Law Infringements: Pros, Cons and Challenges", Concurrences, Revue des Droits de la Concurrence 2-2016 (2016): 19. https://papers.ssrn.com/sol3/papers2.cfm?abstract_id=2782090. See also Florian Wagner-Von Papp, "Criminal Antitrust Law Enforcement in Germany: 'The Whole Point Is Lost if You Keep It a Secret! Why Didn't You Tell the World, Eh?", (2010): 1-2, http://ssrn.com/abstract=1584887, where the author considers the German situation as an example of a well succeeded criminalisation process with exception for the poor communication of the effective results that have been obtained.
} 
the author when he rejects it by defending that neither "popular recognition of conduct as criminal is a necessary condition for criminalising the conduct", nor is there a certitude that "popular opinion would not support criminalisation". ${ }^{38}{ }^{39}$ Regarding the utilitarian perspective, and despite accepting that the success of a criminalisation programme requires "great caution in the implementation", the French and German examples are presented as solid legal systems where that implementation did not affect the effective enforcement of competition law, defending that "[...] where there is a will, there is a way [...]". ${ }^{40}$

Another argument that normally emerges when discussing cartel criminalisation is linked to a corporate governance concern. As CoMbe points out, managers may have a personal interest to involve the undertaking that they have temporary control of in cartels, as the financial and reputational gains obtained in the short term will most probably benefit them. In the long term, taking into account the secrecy of cartels and the difficulty of its detection and punishment, managers may no longer be in functions and it will be the undertaking and in fine its shareholders that will suffer and support the financial sanction imposed. In that view, managers' criminal liability would be a strong incentive for the interests' alignment between managers and shareholders, so that profits maximisation would have to be searched by way of lawful strategies such as innovation and efficiency

\footnotetext{
${ }^{38}$ Wagner-Von Papp, "Introduction - Individual Sanctions", 21. In fact, that argument is not specific to the competition law field but to the entire criminal law spectre and Américo A. Taipa de Carvalho, Direito Penal - Parte Geral. Questões Fundamentais (Porto: Publicações Universidade Católica, 2003): 68-69, considers that it is not for the criminal law to promote ethical-social and ethical-juridical awareness of the fundamental importance of certain values for human social existence, now and in the future, but rather criminal law presupposes that awareness.

${ }^{39}$ Gregory C. Shaffer and Nathaniel H. Nesbitt, "Criminalizing Cartels: A Global Trend?", Legal Studies Research Paper Series (2011): 25, although defending the need for a strong enforcement anti-cartel, consider that the trend for cartel criminalisation seems to be more of a result from a transnational movement rather than from "[...] domestic bottom-up processes". Regardless of this, the fact is that anti-cartel is the only competition area concerned by that transnational movement, and we agree with Toshiaki Takigawa, "Harmonisation of Competition Laws After Doha Substantive and Procedural Harmonisation", Journal of World Trade 36, no. 6 (2002): 1122, when defending that the prohibition of cartels is the only field where an international harmonisation could take place, but it is possible to find other authors, such as Spencer Weber Waller, "Public Choice Theory and the International Harmonisation of Antitrust Law", Antitrust Bulletin 48, no. 2 (2003): 435-436, defending that leniency should also be included in an international harmonisation process.

${ }^{40}$ Wagner-Von Papp, "Introduction - Individual Sanctions", 22.
} 
gains. ${ }^{41}$ On that path, Ginsburg \& Wright go further and defend that effective deterrence would demand sanctions also for the involved employees, and if needed to eliminate gains from the cartel and to reinforce their duty to supervise the managers' activities for the undertaking shareholders as well. ${ }^{42}$

In an apparently more moderate position, we find authors like KHAN defending alternative sanctions for managers previously to an introduction of criminal sanctions. Those alternative sanctions usually consist in director disqualification, occupational bans or similar. ${ }^{43}$ However, we do not see how these personal and very serious sanctions can stop being qualified as criminal sanctions in nature, ${ }^{44}$ as thus we would tend to consider

\footnotetext{
${ }^{41}$ Emmanuel Combe, "Quelles Sanctions Contre les Cartels? Une Perspective Économique”, Revue Internationale de Droit Économique 26, no. 1 (2006): 37. See also Andreas Stephan, "Price Fixing in Crisis: Implications of an Economic Downturn for Cartels and Enforcement", World Competition 35, no. 3 (2012): 516-517, which highlights the fact that the application of financial sanctions to undertakings due to EU competition law breaches occur normally a decade after the infringement, and thus normally it will be different managers and/or shareholders that will end up supporting those sanctions, Emmanuel Combe and Constance Monnier, "Fines against Hard Core Cartels in Europe: The Myth of Overenforcement", Antitrust Bulletin 56, no. 2 (2011): 269, John M. Connor, "Global Cartels Redux: The Amino Acid Lysine Antitrust Litigation (1996)", in The Antitrust Revolution - Economics, Competition and Policy, ed. John E. Kwoka, Jr. and Lawrence J. White (New York: Oxford University Press, 2004): 274, and John M. Connor and Robert H. Lande, "How High Do Cartels Raise Prices? Implications for Optimal Cartel Fines", Tulane Law Review 80 (2005): 559.

${ }^{42}$ Douglas H. Ginsburg and Joshua D. Wright, "Antitrust Sanctions", Competition Policy International 6, no. 2 (2010): 16-20. William E. Kovacic, "An Integrated Competition Policy to Deter and Defeat Cartels", Antitrust Bulletin 51, no. 4 (2006): 816-817, approaches the question differently regarding the employees and defends the existence of positive strategies for motivating the undertakings' employees to denounce cartels, such as granting them the status of informant and a financial reward.

${ }^{43}$ Aaron Khan, "Rethinking Sanctions for Breaching EU Competition Law: Is Director Disqualification the Answer?", World Competition 35, no. 1 (2012): 87 ff., defending that directors' disqualification would produce a higher deterrence effect than criminal sanctions. William J. Kolasky, "Criminalizing Cartel Activity: Lessons from the U.S. Experience", in 5e GCLC Lunch Talk: International Cartel Enforcement (Bruxelas: Collège d'Europe, 2004): 4-5 disagrees and considers that the ultimate deterrence effect comes from jail sanctions.

${ }^{44}$ See Csongor Istvan Nagy, "The Constitutional Court Condemned Hungarian Statute Imposing 'Occupational Ban' on Executives of Cartelist Companies”, European Competition Law Review 30, no. 8 (2009): 2, about the Hungarian example, where the Constitutional Court considered that a proposed sanction of occupational ban to be introduced through an amendment to the Competition Act "[...] being based on personal responsibility and having a quasi-criminal character, demands full-blown judicial review", and therefore did not accept that it could be pursued in an administrative procedure as it was initially intended.
} 
them as more fitted to be alternative and/or cumulative sanctions with other criminal sanctions in a criminal enforcement framework.

In any case, the discussion about the corporate governance argument poses another type of questions, such as proportionality and adequacy of sanctions. Besides the incentives for the alignment of interests between managers and shareholders regarding lawful behaviours, and the reasoning about the "correct" infringers to be sanctioned, the fact is that a balance should be attained in order to fully but proportionally sanction the undertaking and the individual involved in the infringement. NORGREN considers that "[...] developing an administrative system into a dual system would lead to more proportional sanctions", as "[u]nder the administrative system the "perpetrator of the crime" is the company and the sanction in terms of fines is directed to that subject. It is the company's behaviour that is condemned and it is the company that has to pay a price. When adding criminal sanctions against individuals to the system, new issues of a moral nature will emerge. The perpetrator of the crime is still a company, but the individual sanction is applied to an employee that is held responsible for the company's unlawful activities. Violations of antitrust laws may be looked upon as a kind of theft from consumers and society but the thief who goes to prison might be only one of all those individuals carrying out the trespassing of the antitrust rules. If so the system would inhere the risk of merely finding scapegoats and the proportionality could be questioned", thus defending a "criminalisation on top of an administrative system", that would produce a "[...] clear signal to market participants that collusion is not an acceptable behaviour and that there is a personal moral responsibility. The general public would probably view this as a proportionate measure". ${ }^{45}$

One different argument - that we could call practical - is presented by CRANE, favouring the separation of cartel treatment from other competition infringements: in cartel cases "[...] there is no good and bad to balance, merely a factual question whether a bad thing occurred. There is little risk that firms will be chilled from engaging in the appropriate amount of price-fixing, since price-fixing has no social value". ${ }^{46}$ MACCULOCH also

${ }^{45}$ Claes Norgren, "Criminal Enforcement of Antitrust Laws", in Fordham Law Seminar (New York, 2006): 2.

${ }^{46}$ Daniel A. Crane, "Technocracy and Antitrust", Texas Law Review 86 (2007): 48. Christine A. Varney, "Striving for the Optimal Balance in Antitrust Enforcement: Single-Firm Conduct, Antitrust Remedies, and Procedural Fairness" (paper presented at the Council on Foreign 
follows this line of argumentation and brings in addition the intrinsic feature of cartels that can substantially reinforce its differences towards other competition infringements, i.e., the major "wrongdoing" in cartels can be found in the elements of "cheating" and subversion ("subvert competition", "subvert a competitive market" or "subvert the competitive process"). ${ }^{47}$ POSNER also defends the adequacy of criminal sanctions for cartels precisely due to the "conspiracy" character that they present, ${ }^{48}$ and STEPHAN defends cartel criminalisation on the basis of a set of factors, such as the higher deterrence effect of criminal sanctions, the high degree of harm caused by cartels and the secrecy of the conduct, thus converging the "harm" and "moral" arguments. ${ }^{49} 50$

\section{Legal interests that may be protected by competition rules}

Notwithstanding the relevance of the "traditional" arguments relating to cartel criminalisation, we consider the discussion is still incomplete. As it is a discussion about a criminalisation process, the use of common instruments in criminology can shed more light into the question, and one of those instruments - or the most important one - is the analysis of the

Relations, 8.10.2009, New York, 2009): 15, also uses this argument favouring cartel criminalisation as "[...] there is little cause for concern that enforcement will chill pro-competitive or innovative efforts in the marketplace". Werden, "Sanctioning Cartel Activity", 25-26, presents similar arguments, and even Wouter P. J. Wils, "Is Criminalisation of EU Competition Law the Answer?", World Competition 28, no. 2 (2005): 146, despite certain objections concerning the need for a criminalisation process, accepts that bid rigging, price-fixing and market sharing horizontal agreements are the sole competition infringements that do not present potential and unwanted errors of enforcement compared to other competition infringements as in the last "[...] the borderline between anti-competitive and pro-competitive behaviour is often less obvious".

${ }^{47}$ Angus Macculloch, "The Cartel Offence: Defining an Appropriate 'Moral Space", European Competition Journal 8, no. 1 (2012): 75-86.

${ }^{48}$ Richard A. Posner, Antitrust Law - an Economic Perspective. $2^{\text {nd }}$ ed. (Chicago: Chicago Univ. Press, 2001): 52-53. Also Wouter P. J. Wils, "Antitrust Compliance Programmes and Optimal Antitrust Enforcement", Journal of Antitrust Enforcement 1, no. 1 (2013): 77, underlines this aspect, accepting that "Cartels have the further distinguishing characteristic that they are conspiracies between several wrongdoers [...]. This specific characteristic explains the use by competition authorities of leniency programmes". We would add that such a characteristic of conspiracy will not justify a difference only on the "side" of leniency but also on the "side" of the sanction and its nature.

${ }^{49}$ Andreas Stephan, "Four Key Challenges to the Successful Criminalisation of Cartel Laws", Journal of Antitrust Enforcement (2014): 3-7.

${ }^{50}$ In the same line of converging "harm" and "moral" arguments for defending cartel criminalisation, see Peter Whelan, "A Principled Argument for Personal Criminal Sanctions as Punishment under EC Cartel Law", The Competition Law Review 4, no. 1 (2007): 28-39. 
legal interests protected by the norm. ${ }^{51}$ We thus deem essential to complement those arguments with the consideration of what legal interests are harmed in each of the different types of competition infringements, so as to conclude if indeed and to what extent cartels and bid rigging are capable of harming more or different legal interests, or in a different intensity, than those potentially violated by other types of competition infringements.

The first step is to identify what legal interests may be protected by competition rules. It is known that competition law is multivalued ${ }^{52}$ and thus there has been a long discussion on what values should be privileged. ${ }^{53}$ We will not discuss it as it is neither the object of our article nor would it be possible in a short exposition. ${ }^{54}$ The option is then to go through all

${ }^{51}$ As Claus Roxin, "O Conceito de Bem Jurídico como Padrão Crítico da Norma Penal Posto à
Prova". Revista Portuguesa de Ciência Criminal 23, no. 1 (2013): 14, defends, the consideration of
the legal interest protected by the norm is an essential and practical instrument for several aspects
of criminal law, such as for assessing the fundamental decision about the criminalisation of a cer-
tain conduct. With the same understanding see Maria Margarida Silva Pereira, "Bens Jurídicos
Colectivos e Bens Jurídicos Políticos", in Liber Discipulorum Para Jorge De Figueiredo Dias, ed.
Manuel da Costa Andrade, et al. (Coimbra: Coimbra Editora, 2003): 299. A different question is
whether the legal interest may serve as the central element on that assessing of the legitimacy or
illegitimacy of criminal law intervention (as ultima ratio), or as an element that needs to be com-
plemented by other criteria - for a brief analysis of such discussion, see Bernardo Feijoo Sánchez,
"Sobre la Crisis de la Teoría del Bien Jurídico", Indret: Revista para el Análisis del Derecho, no. 2 (2008): 3-16.

${ }^{52}$ This characteristic of competition law is pointed out, for example, by Eleanor M. Fox, "The Modernisation of Antitrust: A New Equilibrium”, Cornell Law Review 66, no. 6 (1981): 1146, relating to the Sherman Act, by Laura Parret, "Shouldn't We Know What We Are Protecting? Yes We Should! A Plea for a Solid and Comprehensive Debate About the Objectives of EU Competition Law and Policy", European Competition Journal 6, no. 2 (2010): 359, and E. Thomas Sullivan and Wolfgang Fikentscher, "On the Growth of the Antitrust Idea", Berkeley Journal of International Law 16 (1998): 230, relating to EU competition law, and by Pedro de Albuquerque, "Direito Português da Concorrência: Em Torno do Decreto-Lei N. ${ }^{\circ} 422 / 83$ ”, Revista da Ordem dos Advogados 50, no. 3 (1990): 592, relating to the Portuguese competition law.

${ }^{53}$ Paul Crampton and Brian A. Facey, "Revisiting Regulation and Deregulation through the Lens of Competition Policy. Getting the Balance Right", World Competition 25, no. 1 (2002): 28-29, highlight the fact that notwithstanding the approval for more than a century of the first competition law, "the goals of competition policy have not been well articulated. Indeed, there is a continuing debate regarding those goals".

${ }^{54}$ It is noteworthy to clarify that there is a distinction between what are desirable objectives of a given situation, and in particular economic ones, of what is the essence, and the values, protected by a given norm (legal interests). As Fernando Castillo de La Torre, "Evidence, Proof and Judicial Review in Cartel Cases", World Competition 32, no. 4 (2009): 508 refers, "The justification of a provision in the law, or the legal interest to be protected, should not be necessarily confused with the conduct which is forbidden by the provision at issue". All the more the distinction is also coher- 
the values/legal interests that have been attributed to EU and Portuguese competition laws, in order to make our comparison between cartels, bid rigging and other types of competition infringements as to violations of legal interests.

The multivalued feature of EU Law has been generally accepted ${ }^{55}$ and GUERRIN \& Kyriazis identify those values as the internal market, consumer protection and optimal allocation of resources and investments, although underlining the fact that cartel control is more motivated by a fundamental objective of controlling economic power accumulation. ${ }^{56}$ HARGITA \& TóTH add the value of transparency ${ }^{57}$ and KoKKORIs reminds us the values of protection of economic freedom and prevention of the use of economic power in detriment to competitive market structures. ${ }^{58}$ Rossi considers the internal market as a fundamental objective to EU competition law without prejudice of also considering that competition defence is an expression of the economic democracy and a guaranty that citizens are

\footnotetext{
ent with the fact that not all interests, even when relevant for a given society, are to be considered as legal interests protected by law and even less as legal interests to be protected by criminal law. On that aspect, see Jorge de Figueiredo Dias, Direito Penal - Parte Geral - Tomo I - Questões Fundamentais. A Doutrina Geral do Crime (Coimbra: Coimbra Editora, 2004): 109-110 and 120121, and Taipa de Carvalho, Direito Penal, 65-66.

${ }^{55}$ Michal S. Gal, "Monopoly Pricing As an Antitrust Offense in the U.S. And the EC: Two Systems of Belief about Monopoly", The Antitrust Bulletin Spring-Summer (2004): 362, considers the EU competition policy based on "[...] broad, and sometimes conflicting, aims that are concerned not only with promoting economic efficiency and a free market economy, but also with achieving broader social and political goals, most notably the creation of a single, integrated European market". David J. Gerber, "Modernising European Competition Law: A Developmental Perspective", European Competition Law Review 22, no. 4 (2001): 124, refers to a "multi-layered system of European competition law", where protecting competition may present several meanings, such as protecting economic efficiency, protecting economic freedom, controlling economic power, but in the EU also means promoting the integration objective. See also David J. Gerber, "The Transformation of European Community Competition Law", Harvard International Law Journal 35, no. 1 (1994): 98.

${ }^{56}$ Maurice Guerrin and Georgios Kyriazis, "Cartels: Proof and Procedural Issues", Fordham Corp. L. Inst. 1992 (B. Hawk, org., 1993): 778-779.

${ }^{57}$ Árpád Hargita and Tihamér Tóth, "God Forbid Bid-Riggers: Developments under the Hungarian Competition Act", World Competition 28, no. 2 (2005): 205. Barry E. Hawk, "La Révolution Antitrust Américaine: Une Leçon pour la Communauté Économique Européenne?", Revue Trimestrielle de Droit Européen 25, no. 1 (1989): 28-31, defends that due to the Ordoliberal roots of EU competition law, the value of loyalty is likewise included. See also James C. Cooper, Luke Froeb, Daniel P. O’Brien, and Michael Vita, "A Comparative Study of United States and European Union Approaches to Vertical Policy”, George Mason Law Review 13, no. 2 (2005): 289. ${ }^{58}$ Ioannis Kokkoris, "Should Crisis Cartels Exist amid Crises?", Antitrust Bulletin 55, no. 4 (2010): 732 .
} 
able to express their way of life and well-being, namely through freedom of choice and protection of the private property model..$^{59}$ Pera shares his "ordoliberal view of competition", defending that the EU Treaty is founded on a vision of "ensuring a free market economy in a free society", with the idea of a "competitive market system [...] placed at the centre of a free political order [...]. From this point of view, a free competitive market has not only economic but also social value". ${ }^{60}$

Without prejudice of still considering the internal market as a fundamental value to be defended, Sullivan \& Fikentscher emphasise the evolution of EU competition policy values ${ }^{61}$ and PAIs rightly points out that as the accomplishment of the single market objective becomes a reality, the "constitutional" defence of economic integration reduces its central importance towards the recognition of a more important role for the values of consumer defence and efficiency. ${ }^{62}$ Nevertheless, we find that at

${ }^{59}$ Guido Rossi, “Antitrust e Teoria della Giustizia”, Rivista delle Società 40, no. 1 (1995): 3, 7, 10-11, 21. Christopher Bright, "EU Competition Policy: Rules, Objectives and Deregulation", Oxford Journal of Legal Studies 16, no. 4 (1996): 596, refers to the internal market value as a "Single Market 'Grundnorm', Patrick Van Cayseele and Roger J. Van den Bergh, "Antitrust Law", in Encyclopedia of Law and Economics, ed. Boudewijn Bouckaert and Gerrit de Geest (Cheltenham: Edward Elgar Publ., 2000): 484, consider that the objective of EU competition policy "[...] has always been the promotion of market integration". Manfred Caspari, "1992 - EEC Competition Law and Industrial Policy", Fordham Corp. L. Inst. 1989 (B. Hawk, org., 1990) (1990): 169, defends that "Internal market policy is [...] also competition policy", Kamiel J. M. Mortelmans, "Towards Convergence in the Application of the Rules on Free Movement and Competition?", Common Market Law Review 38, no. 3 (2001): 623 presents the "common market as a level playing field" and David J. Gerber, "Competition Law and the WTO: Rethinking the Relationship". Journal of International Economic Law 10, no. 3 (2007): 721, defends the link between control of economic power and market integration.

${ }^{60}$ Cfr. Alberto Pera, "Changing Views of Competition, Economic Analysis and EC Antitrust Law", European Competition Journal 4, no. 1 (2008): 145-146. It is noteworthy that Oles Andriychuk, "Rediscovering the Spirit of Competition: On the Normative Value of the Competitive Process", European Competition Journal 6, no. 3 (2010): 583-584 refers to the "constitutional importance of competition", and also Daniel J. Gifford and Robert T. Kudrle, "European Union Competition Law and Policy: How Much Latitude for Convergence with the United States?", Antitrust Bulletin 48, no. 2 (2003): 779, highlight the importance of the competitive process as central for the protection of other fundamental principles, and for a summary of the discussion concerning the inclusion in the EU competition law of values not necessarily related with efficiency values, see Okeoghene Odudu, "The Wider Concerns of Competition Law", Oxford Journal of Legal Studies 30, no. 3 (2010): 599-613.

${ }^{61}$ Sullivan and Fikentscher, "On the Growth of the Antitrust Idea", 230, 232.

${ }^{62}$ Sofia Oliveira Pais, Entre Inovação e Concorrência - Em Defesa de um Modelo Europeu (Lisboa: Universidade Católica Editora, 2011): 595-605. Parret, "Shouldn’t We Know What We Are Protecting?", 357-358, also points out a "Consumer Emphasis since Modernisation”, precisely 


\section{the present time that openness to other values shall still be through the internal market fundamental value. ${ }^{63}$}

underlining the evolution process of the relative importance of the different EU competition policy values, notwithstanding the fact that Alison Jones, "Analysis of Agreements under U.S. and EC Antitrust Law - Convergence or Divergence?". Antitrust Bull. 51, no. 4 (2006): 741-743 qualifies the situation as "[a] further complication [...] that the goal or goals of EC competition law remain unsettled", criticising the fact that the ECJ continues to read Articles 101 and 102 "against the wider backdrop of the Treaty aims and objectives, particularly the goal of single market integration and open market access". Also Anne C. Witt, "Public Policy Goals under EU Competition Law - Now Is the Time to Set the House in Order". European Competition Journal 8, no. 3 (2012): 469, considers that "The Court of Justice [...] does not read the competition rules in isolation from other policy aims, but continues to interpret them in light of the Treaties as a whole", in a view that is also defended, for example, by Giorgio Monti, "Article 81 EC and Public Policy". Common Market Law Review 39, no. 5 (2002): 1057, that "competition policy cannot be implemented in a vacuum, but must be consistent with the development of the European project". However, it is clear that despite the discussion about EU competition policy values, the internal market value continues to be a central one, as Neelie Kroes, "Competition Policy and the Crisis - the Commission's Approach to Banking and Beyond", Antitrust Bulletin 55, no. 4 (2010): 716, stressed: "Competition policy may not be loved by all governments and competitors, but the need for it to act as the backbone of the EU Single Market remains substantially unchallenged. [...] we can never drop our defences against protectionism [...]. Indeed, the case for a continuing level playing field in Europe is stronger than ever".

${ }^{63}$ As Philip Lowe and Ansgar Held, "Modernisation and Beyond: The Role of Competition Policy in Driving Economic Growth", European Competition Journal 1, no. 1 (2005): 35, defend "a proactive competition policy [...] facilitates business activity, dissemination of knowledge, a better deal for consumers, and efficient economic restructuring throughout the internal market; and an enforcement practice which removes barriers to entry and impediments to effective competition that most seriously harm competition in the internal market and imperil the competitiveness of European enterprises". That view facilitates the separation between EU competition law and Member-States' competition laws, as EU law is not applicable to purely internal situations - see Koen Lenaerts and Piet Van Nuffel, Constitutional Law of the European Union (London: Sweet \& Maxwell, 1999): 119-120 -, neither an objective of national competition laws to defend European economic integration and the European internal market - Fátima Reis Silva, "Um Olhar "Comercial" sobre o Direito Contra-Ordenacional", Julgar, no. 8 (2009): 106 -, and internal market is clearly a legal interest that is attributed to the EU once it is accepted that it can be recognised that EU has its own legal interests to defend - in that sense, see Pedro Caeiro, "Perspectivas de Formação de um Direito Penal da União Europeia”, in Direito Penal Económico e Europeu: Textos Doutrinários (Coimbra: Coimbra Editora, 1998): 528 -, thus avoiding ne bis in idem situations that, as Wouter P. J. Wils, "The Principle of Ne Bis in Idem in EC Antitrust Enforcement: A Legal and Economic Analysis", World Competition 26, no. 2 (2003): 143-144, rightly points, becomes even more obvious since the decentralisation process triggered by Regulation 1/2003. On the aspect of parallel and cumulative application of $\mathrm{EU}$ and national competition laws, see also Fréderic Louis and Gabriele Accardo, "Ne Bis in Idem, Part 'Bis', World Competition 34, no. 1 (2011): 101, Miguel Moura e Silva, "As Práticas Restritivas da Concorrência na Lei N. . 19/2012 Novos Desenvolvimentos", in O Novo Regime Jurídico da Concorrência (Universidade Católica Portuguesa - Lisboa: Autoridade da Concorrência, 2012): 6-7, Renato Nazzini, "Fundamental 
Consequently, the main legal interest of EU competition law is - or continues to be - the defence of the internal market, where other values will also be considered, such as the control of economic power, defence of freedom (of individuals and companies, freedom of action and decision-making, freedom of market access and freedom of choice), defence of transparency and of the private property model, and consumer protection.

Turning to the Portuguese case, the legislator has been over the years quite clear on what values and legal interests he intends to protect. In the first Portuguese Competition Act of $1983,{ }^{64}$ the legislator clearly explained in the preamble that:

\begin{abstract}
"the protection of competition is [...] one of the essential instruments of economic policy, and it is commonly recognized that it produces two main virtues: guaranteeing consumers a diversified choice of goods and services, in the best conditions of quality and price, and to stimulate companies to rationalize the production and distribution of goods and services to the maximum extent possible and to constantly adapt to technical and scientific progress".
\end{abstract}

Within the Competition Act of $1993^{65}$ express reference was made to Article 81(f) of the Constitution ${ }^{66}$ and its objectives were to contribute "to the freedom of supply and demand formation and access to the market, to the good balance of economic relations between agents, to the promotion of the general objectives of economic and social development, to strengthen the competitiveness of economic agents and to safeguard the

Rights beyond Legal Positivism: Rethinking the Ne Bis in Idem Principle in EU Competition Law", Journal of Antitrust Enforcement (2014): 18, Aurelio Pappalardo, "Les Relations Entre le Droit Communautaire et les Droits Nationaux de la Concurrence", Revue Internationale de Droit Économique 9, no. 1 (1995): 147-149, and Jürgen Schwarze, "Les Sanctions Imposées pour les Infractions au Droit Européen de la Concurrence selon l'Article 23 du Règlement No 1/2003 CE à la Lumière des Principes Généraux du Droit", Revue Trimestrielle de Droit Européen 43, no. 1 (2007): 18-19. As to the jurisprudence of the ECJ, see Judgements of 13 February 1969, Walt Wilhelm e. o. c. Bundeskartellamt, C-14/68, ECLI:EU:C:1969:4 and Judgment of 7 January 2004, Aalborg Portland A/S, C-204/00 P, ECLI:EU:C:2004:6.

${ }^{64}$ Decreto-Lei n. ${ }^{\circ} 422 / 83$.

${ }^{65}$ Decreto-Lei n. ${ }^{0} 371 / 93$.

${ }^{66}$ Establishing the constitutional task for the State to guarantee "the efficient functioning of markets so as to ensure balanced competition between undertakings, to repress monopolistic forms of organisation, abuses of dominant position and other harmful practices of general interest". 
interests of consumers". ${ }^{67}$ In the 2003 reform the statutes of the Portuguese Competition Authority contained the legislator's intention to "promote the efficient functioning of markets, the efficient allocation of national resources and, above all, the satisfaction of consumers' interests", ${ }^{68}$ and its actual statutes establish its duty to enforce competition law "in respect of the principle of a free market economy and free competition, aiming at the efficient functioning of markets, the optimal allocation of resources and the interests of consumers" ${ }^{69}$

The Portuguese competition laws have thus been presented as a key instrument of economic policy, a guarantee of freedom of choice for consumers, a stimulus to enterprises for maximum rationalisation of the production and distribution of goods and services, and encouragement for constant adaptation to technical and scientific progress, a determinant of greater market transparency and promotion of economic structures competitiveness, in favour of freedom of supply and demand formation and access to the market, thereby favouring the general objectives of economic and social development, strengthening the competitiveness of economic agents and safeguarding consumers' interests.

When referring those objectives back to the legal interests' lexicon in competition law, we can conclude that the legal interests defended by the Portuguese competition law consubstantiate in the control of the economic power, defence of the freedom of individuals and companies (freedom of action, freedom of decision, freedom to market access and freedom of choice), consumer protection, as well as defence of market transparency and confidence and defence of the private property model.

\section{Application of the legal interests approach}

Accepting the legal scholarship and jurisprudential consensus on the qualification of cartels as the most serious conduct in competition infringements is in itself sufficient to justify the differentiation of cartels from other anti-competitive practices, we consider that an additional analysis based on the legal interests is beneficial to justify that same differentiation, and the summary of the "harmonisation" of competition objectives with

\footnotetext{
${ }^{67}$ See the preamble of Decreto-Lei n. ${ }^{\circ} 371 / 93$.

${ }^{68}$ See the preamble of Decreto-Lei n. ${ }^{\circ} 10 / 2003$.

${ }^{69}$ Article 1(3) of the statutes approved by Decreto-Lei n. ${ }^{\circ} 125 / 2014$.
} 
legal interests and our appreciation of its violations in different competition infringements is as follows: ${ }^{70}$

\begin{tabular}{|c|c|c|c|c|}
\hline $\begin{array}{c}\text { Competition } \\
\text { objectives }\end{array}$ & $\begin{array}{c}\text { Legal interests } \\
\text { defended by } \\
\text { competition laws }\end{array}$ & $\begin{array}{l}\text { Violation of } \\
\text { legal interests } \\
\text { in cartel } \\
\text { situations and } \\
\text { intensity }\end{array}$ & $\begin{array}{c}\text { Violation of } \\
\text { legal interests } \\
\text { in bid rigging } \\
\text { situations and } \\
\text { intensity }\end{array}$ & $\begin{array}{l}\text { Violation of legal } \\
\text { interests in other } \\
\text { competition } \\
\text { infringements and } \\
\text { intensity }\end{array}$ \\
\hline $\begin{array}{c}\text { Economic } \\
\text { power control }\end{array}$ & $\begin{array}{l}\text { Economic power } \\
\text { control }\end{array}$ & $\begin{array}{c}\text { Yes } \\
\text { High }\end{array}$ & $\begin{array}{c}\text { Yes } \\
\text { High }\end{array}$ & $\begin{array}{c}\text { Potential in vertical } \\
\text { restraints } \\
\text { Low or Medium } \\
\text { Yes on abuse of } \\
\text { dominant position } \\
\text { High }\end{array}$ \\
\hline $\begin{array}{c}\text { Competitive } \\
\text { process }\end{array}$ & $\begin{array}{c}\text { Freedom of } \\
\text { individuals and } \\
\text { companies (freedom } \\
\text { of action, freedom } \\
\text { of decision, freedom } \\
\text { to market access and } \\
\text { freedom of choice) }\end{array}$ & $\begin{array}{c}\text { Yes } \\
\text { High }\end{array}$ & $\begin{array}{c}\text { Yes } \\
\text { High }\end{array}$ & $\begin{array}{c}\text { Potential in vertical } \\
\text { restraints } \\
\text { Low or Medium } \\
\text { Yes on abuse of } \\
\text { dominant position } \\
\text { High }\end{array}$ \\
\hline $\begin{array}{l}\text { Competitive } \\
\text { structure }\end{array}$ & $\begin{array}{c}\text { Freedom of } \\
\text { individuals and } \\
\text { companies (freedom } \\
\text { of action, freedom } \\
\text { of decision, freedom } \\
\text { to market access and } \\
\text { freedom of choice) }\end{array}$ & $\begin{array}{c}\text { Yes } \\
\text { High }\end{array}$ & $\begin{array}{c}\text { Yes } \\
\text { High }\end{array}$ & $\begin{array}{c}\text { Potential in vertical } \\
\text { restraints } \\
\text { Low or Medium } \\
\text { Yes on abuse of } \\
\text { dominant position } \\
\text { High }\end{array}$ \\
\hline $\begin{array}{c}\text { Freedom of } \\
\text { individuals } \\
\text { and companies }\end{array}$ & $\begin{array}{c}\text { Freedom of } \\
\text { individuals } \\
\text { and companies } \\
\text { (freedom of } \\
\text { action, freedom of } \\
\text { decision, freedom } \\
\text { to market access } \\
\text { and freedom of } \\
\text { choice) }\end{array}$ & $\begin{array}{c}\text { Yes } \\
\text { High }\end{array}$ & $\begin{array}{c}\text { Yes } \\
\text { High }\end{array}$ & $\begin{array}{c}\text { Potential in vertical } \\
\text { restraints } \\
\text { Low or Medium } \\
\text { Yes on abuse of } \\
\text { dominant position } \\
\text { High }\end{array}$ \\
\hline
\end{tabular}

\footnotetext{
${ }^{70}$ Reminding that the main legal interest of EU competition law still is the defence of the internal market, where the other values, such as the control of economic power, defence of freedom (of individuals and companies, freedom of action and decision-making, freedom of market access and freedom of choice), defence of transparency and of the private property model, and consumer protection, shall be considered.
} 


\begin{tabular}{|c|c|c|c|c|}
\hline $\begin{array}{c}\text { Competition } \\
\text { objectives }\end{array}$ & $\begin{array}{l}\text { Legal interests } \\
\text { defended by } \\
\text { competition laws }\end{array}$ & $\begin{array}{l}\text { Violation of } \\
\text { legal interests } \\
\text { in cartel } \\
\text { situations and } \\
\text { intensity }\end{array}$ & $\begin{array}{c}\text { Violation of } \\
\text { legal interests } \\
\text { in bid rigging } \\
\text { situations and } \\
\text { intensity }\end{array}$ & $\begin{array}{l}\text { Violation of legal } \\
\text { interests in other } \\
\text { competition } \\
\text { infringements and } \\
\text { intensity }\end{array}$ \\
\hline Rivalry & $\begin{array}{c}\text { Freedom of } \\
\text { individuals } \\
\text { and companies } \\
\text { (freedom of } \\
\text { action, freedom of } \\
\text { decision, freedom } \\
\text { to market access } \\
\text { and freedom of } \\
\text { choice) }\end{array}$ & $\begin{array}{c}\text { Yes } \\
\text { High }\end{array}$ & $\begin{array}{c}\text { Yes } \\
\text { High }\end{array}$ & $\begin{array}{c}\text { Potential in vertical } \\
\text { restraints } \\
\text { Low or Medium } \\
\text { Yes on abuse of } \\
\text { dominant position } \\
\text { High }\end{array}$ \\
\hline $\begin{array}{l}\text { Differentiation } \\
\text { by innovation }\end{array}$ & $\begin{array}{c}\text { Freedom of } \\
\text { individuals } \\
\text { and companies } \\
\text { (freedom of } \\
\text { action, freedom of } \\
\text { decision, freedom } \\
\text { to market access } \\
\text { and freedom of } \\
\text { choice) }\end{array}$ & $\begin{array}{c}\text { Yes } \\
\text { High }\end{array}$ & $\begin{array}{c}\text { Yes } \\
\text { High }\end{array}$ & $\begin{array}{c}\text { Potential in vertical } \\
\text { restraints } \\
\text { Low or Medium } \\
\text { Yes on abuse of } \\
\text { dominant position } \\
\text { High }\end{array}$ \\
\hline \multirow[t]{5}{*}{$\begin{array}{l}\text { Consumer } \\
\text { protection }\end{array}$} & $\begin{array}{l}\text { Consumer } \\
\text { protection }\end{array}$ & $\begin{array}{c}\text { Yes } \\
\text { High }\end{array}$ & $\begin{array}{c}\text { Yes } \\
\text { High }\end{array}$ & $\begin{array}{c}\text { Potential in vertical } \\
\text { restraints } \\
\text { Low or Medium } \\
\text { Yes on abuse of } \\
\text { dominant position } \\
\text { High }\end{array}$ \\
\hline & Confidence & $\begin{array}{c}\text { Yes } \\
\text { High }\end{array}$ & $\begin{array}{c}\text { Yes } \\
\text { High }\end{array}$ & No \\
\hline & Transparency & $\begin{array}{c}\text { Yes } \\
\text { High }\end{array}$ & $\begin{array}{c}\text { Yes } \\
\text { High }\end{array}$ & No \\
\hline & Property & $\begin{array}{c}\text { Yes } \\
\text { High }\end{array}$ & $\begin{array}{c}\text { Yes } \\
\text { High }\end{array}$ & $\begin{array}{c}\text { Potential in vertical } \\
\text { restraints } \\
\text { Low or Medium } \\
\text { Yes on abuse of } \\
\text { dominant position } \\
\text { High }\end{array}$ \\
\hline & $\begin{array}{l}\text { Property (public } \\
\text { treasury) and } \\
\text { control of } \\
\text { economic power }\end{array}$ & No & $\begin{array}{c}\text { Yes } \\
\text { High }\end{array}$ & $\begin{array}{c}\text { Potential on abuse } \\
\text { of dominant } \\
\text { position }\end{array}$ \\
\hline
\end{tabular}




\begin{tabular}{|c|c|c|c|c|}
\hline $\begin{array}{c}\text { Competition } \\
\text { objectives }\end{array}$ & $\begin{array}{c}\text { Legal interests } \\
\text { defended by } \\
\text { competition laws }\end{array}$ & $\begin{array}{l}\text { Violation of } \\
\text { legal interests } \\
\text { in cartel } \\
\text { situations and } \\
\text { intensity }\end{array}$ & $\begin{array}{c}\text { Violation of } \\
\text { legal interests } \\
\text { in bid rigging } \\
\text { situations and } \\
\text { intensity } \\
\end{array}$ & $\begin{array}{l}\text { Violation of legal } \\
\text { interests in other } \\
\text { competition } \\
\text { infringements and } \\
\text { intensity }\end{array}$ \\
\hline & $\begin{array}{l}\text { Property (fiscal) } \\
\text { and control of } \\
\text { economic power }\end{array}$ & No & $\begin{array}{c}\text { Yes } \\
\text { High }\end{array}$ & No \\
\hline Redistribution & $\begin{array}{c}\text { Control of } \\
\text { economic power }\end{array}$ & $\begin{array}{c}\text { Yes } \\
\text { High }\end{array}$ & $\begin{array}{c}\text { Yes } \\
\text { High }\end{array}$ & $\begin{array}{c}\text { Potential in vertical } \\
\text { restraints } \\
\text { Low or Medium } \\
\text { Yes on abuse of } \\
\text { dominant position } \\
\text { High }\end{array}$ \\
\hline $\begin{array}{c}\text { Efficiency } \\
\text { and welfare } \\
\text { maximisation }\end{array}$ & $\begin{array}{c}\text { Freedom of } \\
\text { individuals } \\
\text { and companies } \\
\text { (freedom of } \\
\text { action, freedom of } \\
\text { decision, freedom } \\
\text { to market access } \\
\text { and freedom of } \\
\text { choice) }\end{array}$ & $\begin{array}{c}\text { Yes } \\
\text { High }\end{array}$ & $\begin{array}{c}\text { Yes } \\
\text { High }\end{array}$ & $\begin{array}{c}\text { Potential in vertical } \\
\text { restraints } \\
\text { Low or Medium } \\
\text { Yes on abuse of } \\
\text { dominant position } \\
\text { High }\end{array}$ \\
\hline
\end{tabular}

Before going through all the competition objectives and related legal interests to explain our understanding, one first and basic distinction between cartels and vertical restraints must be recalled. As vertical agreements are concluded between undertakings at different stages in the production process, they do not present a high degree of concern. And as normally vertical restrictions' impact is centred in intra-brand competition, it has been accepted that the only vertical restraints raising welfare concerns are those adopted by firms which enjoy enough market power. ${ }^{71}$ That is the reason why e.g. Regulation (EU) 330/2010 establishes a legal presumption that positive effects of vertical agreements outweigh potential competitive constraints in cases where market share of the undertakings does not exceed $30 \%$ of the relevant market. And also the reason why an economic balance may be carried out, and even when the exemption requirements are not met such a breach will be of low or medium intensity, in the sense

${ }^{71}$ Massimo Motta, Competition Policy: Theory and Practice (Cambridge: Cambridge University Press, 2004): 306. 
that since it is not carried out by competitors its impact for the competitive market structure and/or for the competitive process is not comparable to an agreement between competitors. And so BoRK, known for his extreme position of a minimal intervention of competition law, defended that "A per se rule against cartels is thus sound policy", ${ }^{72}$ by contrast with his understanding that "[...] antitrust should have no concern with vertical restraints; all should be lawful". ${ }^{73}$

Having made this fundamental distinction, the consideration of the negative impact of cartels in the legal interest of economic power control is the following step of our analysis. And indeed a cartel is one of the most relevant examples of the possibility of a direct and intense attack on it, impairing the fundamental principle of "the subordination of economic power to democratic political power" ${ }^{74}$ The European experience and history cannot be forgotten as they provide e.g. the German example where cartels were effectively used as means of economic power concentration and "[...] instruments of political or economic aggression", ${ }^{75}$ in a context in which "In Germany, since 1879, cartels [were] used for three purposes: i) to satisfy the profit hunger of private business organisations; 2) at the same time to win influence over the political and economic organisation of the nation on behalf of private interests; 3 ) to serve as a means of governmental and political power". ${ }^{76}$ Take also the example of a market sharing cartel aiming at secretly re-establishing "invisible" national boarders for the goods or services cartelised: it is obviously an attack to the internal market objective but it represents in ultima ratio a direct attack to the political and fundamental decision of developing an economic integration at a supranational level. Likewise, bid rigging constitutes a serious and intense attack on the control of economic power legal interest, since a price cartel will necessarily end up with public services buying goods or services at a higher price and as public financial resources are scarce, the damage caused by the cartel will also correspond to the public resources that will no longer be available for other needs or public policies.

\footnotetext{
${ }^{72}$ Robert H. Bork, "Contrasts in Antitrust Theory: I", Columbia Law Review 65, no. 3 (1965): 410.

${ }^{73}$ Robert H. Bork, "Vertical Restraints: Schwinn Overruled", The Supreme Court Review (1977): 182.

${ }^{74}$ See, for Portugal, Article 80(a) of the Constitution.

${ }^{75}$ Hannah L. Buxbaum, "German Legal Culture and the Globalisation of Competition Law: A Historical Perspective on the Expansion of Private Antitrust Enforcement", Berkeley Journal of International Law 23, no. 2 (2005): 104.

${ }^{76}$ Heinrich Kronstein, "The Dynamics of German Cartels and Patents. I", University of Chicago Law Review 9, no. 4 (1942): 645.
} 
An abuse of dominant position will also be able to directly confront the economic power control legal interest. But differently to cartels, most of the time that confrontation will be noticed immediately, allowing for a reaction at the right time. And in its more extreme form, where all the relevant players of a market are involved, a cartel can virtually empower each and every one of its members as a monopolist.

In relation to freedom of individuals and companies (freedom of action, freedom of decision, freedom to market access and freedom of choice), a cartel possesses all the characteristics to severely infringe that legal interest. It is the complete opposition of the idea of a competitive process and rivalry that is expected to occur in a competitive market structure. A cartel is the denial of the competitive process with its members eliminating by collusion the competitive pressure and mutual rivalry, and "knowingly substitutes practical cooperation between them for the risks of competition,", and under an appearance of market players diversity they secretly act obeying to one and sole secret strategy. That is also why a cartel gravely undermines the market's competitive structure, as what would be expected from a market structure with several players was the natural competitive outcome, but the cartel secretly falsifies those market characteristics and brings them closer to other market structure models that, in the extreme example of a cartel involving all the relevant players, may be close to monopoly.

The negative impact of a cartel in differentiation is also quite relevant, as the elimination of competitive pressure reduces the need e.g. for product, price, quality or innovation differentiation. Cartel members know that clients will be limited in their choices and consequently have no need to invest in strategies that otherwise would be needed to keep or attract clients, and the possibility of charging supra-competitive prices even without those investments to "locked-in" clients represents an (illegal) benefit that no economic agent would think possible in a normal situation. The benefits for cartel members represent a loss of economic efficiency - in all its possible ways, such as productive, allocative or innovation efficiency -, and also allow cartel members to maintain their inefficiencies - namely Xinefficiency ${ }^{78}$ - that are necessarily transmitted to the undertaking stake-

${ }^{77}$ ECJ Judgement of 14 July 1972, Imperial Chemical Industries (ICI) c. Commission, 48/69, ECLI:EU:C:1972:70, paragraph 64.

${ }^{78}$ See Harvey Leibenstein, "Allocative Efficiency vs. 'X-Efficiency', American Economic Review 56, no. 3 (1966): 392-413, and George J. Stigler, “The Xistence of X-Efficiency”, American Economic Review 66, no. 1 (1976): 213-216. 
holders (clients, suppliers, partners, shareholders, etc.) and therefore to the society.

The consequence is that a cartel not only seriously affects welfare maximisation, but also directly harms multiple and essential aspects of the freedom of individuals. Since freedom of economic initiative is one of the fundamental principles of economic and social organisation, ${ }^{79}$ a cartel that, among other collusive aspects, has elements of reaction and elimination of other or new competitors is an example of an illegitimate attack on such freedom of economic initiative, dishonestly hindering or even impeding others from entering the market and/or from exercising their freedom of choice of profession. ${ }^{80}$ And a cartel that results in an absence of price or product differentiation, or even in a client sharing scheme, distorts freedom of action, decision and materially impedes the freedom of choice of those affected.

An abuse of a dominant position has a similar capacity to violate the freedom of individuals and companies (freedom of action, freedom of decision, freedom to market access and freedom of choice), being highly harmful for the competitive process, the competitive market structure and for innovation promotion, and is, therefore, also detrimental to efficiency and maximisation of welfare.$^{81}$ But a cartel produces a similar harm in a secret, dissimulated and subversive way, adding the elements of "cheating", subversion of competition, subversion of a competitive market and subversion of the competitive process. ${ }^{82}$

Consumer protection is also impaired by a cartel. It is a constitutional right for the consumers to have access to the quality of goods and services that they buy, as well as to be safeguarded in what relates to health and

\footnotetext{
${ }^{79}$ For Portugal, see Articles 61 and 80 (c) of the Constitution.

${ }^{80}$ Freedom of choice of profession is also constitutionally protected - for Portugal, see Article 47(1) of the Constitution.

${ }^{81}$ Pais, Entre Inovação e Concorrência, 458-461. And as Christopher R. Leslie, "Antitrust Damages and Deadweight Loss", Antitrust Bull. 51, no. 3 (2006): 566-567, mentions, "Antitrust violations, such as illegal monopolisation and cartelisation, create inefficiency and social harm in the form of deadweight loss. Antitrust theorists recognise that deadweight loss represents antitrust harm because consumers are being denied the ability to purchase a product even though they are willing and able to pay a price that is greater than the cost of production and because additional units would be available at or below a price that consumers could afford if the product were sold in a competitive market. Despite the widespread recognition of deadweight loss as an antitrust injury, antitrust jurisprudence fails to consider this injury as an element of antitrust damages".

${ }^{82}$ Macculloch, "The Cartel Offence", 75-86.
} 
safety risks and to have their economic interests protected..$^{83}$ As KoKKORIS points out, cartels normally engage in "[...] price fixing, market division, control of output, mitigation of technological improvement, and limiting of production". ${ }^{84}$ When consumers are obliged to pay a cartelised price, i.e. supra-competitive, their economic interests are certainly not being respected. And when they are prevented from accessing differentiated, improved or innovative products, as a result of concertation on sales and/ or technological development, their rights to the quality of goods are also being infringed, as the quality of the goods from which they can choose is only that one decided by cartel members.

The same argument applies to the case of abuse of dominance, since in the extreme case of monopoly, used to facilitate the exemplification, consumers will bear the price, availability and quality of the products that the monopolist producer has decided. But again we see a difference: the consumer will normally realise that he is facing a monopolist, and can react with the decision that still remains in his hands - not considering the damage that may result therefrom - that is to decide not to acquire the product. On the contrary, in the case of the cartel, consumers do not have such a prior perception, believing that they are interacting with one of several agents offering the product and believing that they are able to choose freely and according to their parameters.

This aspect is also a very relevant one when considering the confidence legal interest. It seems to us that anyone who interacts with a dominant firm will not have the same degree of confidence in the negotiation and/ or contractual balance as when interacting and negotiating with a company that is believed to be in a competitive process with others on the same product/service market. Putting it in a different way, the relevant market competitive structure is already weakened by the existence of a dominant firm, ${ }^{85}$ and it will be more easily perceived by counterparts that the dominant firm will be less sensitive to "consumer sovereignty" ${ }^{86}$ due to limited or even absent alternatives. The confidence that counterparts put in the dominant firm will expectably be quite inferior - or non-existing -

${ }^{83}$ For Portugal, see Article 60(1) of the Constitution.

${ }^{84}$ Kokkoris, "Should Crisis Cartels Exist", 728.

${ }^{85}$ In that sense, see the ECJ Judgement of 9 November 1983, NV Nederlandsche Banden-IndustrieMichelin, 322/81, ECLI:EU:C:1983:313, paragraph 57, and Judgment of 16 March 2000, Compagnie Maritime Belge Transports SA e.o., C-395/96 P and C-396/96 P, ECLI:EU:C:2000:132, paragraph 113. ${ }^{86}$ Rhonda L. Smith and Stephen King, "Does Competition Law Adequately Protect Consumers?", European Competition Law Review 28, no. 7 (2007): 413. 
as compared to when they consider that they are negotiating with a firm that is rivalling to be successful at selling them the product or service and for that is presumably following an independent and autonomous market strategy. Therefore, confidence will be much more disrupted in a cartel situation.

That is precisely why the transparency legal interest is profoundly harmed in cartel situations. Their secret character continues to give them the Smithian "conspiracy against the public" element, ${ }^{87}$ and the British experience is quite elucidative on that aspect. Cartel criminalisation was introduced by the Enterprise Act de 2002, establishing in paragraph 188(1) the "cartel offence" as "An individual [is] guilty of an offence if he dishonestly agrees with one or more other persons to make or implement, or to cause to be made or implemented, arrangements of the following kind relating to at least two undertakings [...]",., with paragraph 188(2) listing the arrangements to which the cartel offence would be applicable, including bid rigging. The cartel offence was thus centred in the "dishonesty" element. In the Enterprise and Regulatory Reform Act of 2013, an amendment was introduced in the cartel offence, eliminating the reference to "dishonesty" in paragraph 188(1), so as to facilitate its enforcement, and paragraph $188 \mathrm{~A}$ was added, establishing the "Circumstances in which cartel offence not committed" that constitute exclusions to the cartel offence. Those exclusions refer to the publicity or knowledge (absence of secrecy) of the cartel, and therefore a cartel offence is not committed when relevant information is provided to clients, suppliers, etc., relating the arrangements where the undertaking is involved. And so the cartel offence switched from a sanctioning approach based on the "dishonesty" to a sanctioning approach based on the "secrecy" of cartels, and so sanctioning the "conspiracy" and the violation of the legal interest of transparency. ${ }^{88}$

\footnotetext{
${ }^{87}$ Adam Smith, A Riqueza das Nações, trans. Alexandre Amaral Rodrigues and Eunice Ostrensky (São Paulo: Livraria Martins Fontes, 2003): 165.

${ }^{88}$ For the analysis of the UK competition law and the cartel offence, see O'Kane, "Does Prison Work for Cartelists?", 488-490; Peter Freeman, “Beware the Ides of March' - the Government's Proposed Competition Reforms", European Competition Journal 8, no. 3 (2012): 570-571; Peter Freeman, "The Competition and Markets Authority: Can the Whole Be Greater Than the Sum of Its Parts?", Journal of Antitrust Enforcement 1, no. 1 (2013): 4-23; Cosmo Graham, "The Reform of UK Competition Policy", European Competition Journal 8, no. 3 (2012): 539-562; Alison Jones and Rebecca Williams, "The UK Response to the Global Effort against Cartels: Is Criminalisation Really the Solution?", Journal of Antitrust Enforcement 2, no. 1 (2014): 100-125; Julian M. Joshua, "The UK's New Cartel Offence and Its Implications for EC Competition Law: A Tangled Web", European Law Review 28, no. 5 (2003): 620-641; William E. Kovacic and David A. Hyman,
} 
And the fact is that cartels are the sole competition infringement that have that strong and inherent aptitude to confront transparency through conspiracy, ${ }^{89}$ as an abuse of dominant position is a unilateral conduct and so without this feature of various competitors conspiring to cheat their clients or other counterparts. On the contrary, it is from the revealed behaviour in the market by a dominant firm that an eventual abuse - either related to exploitation or exclusion ${ }^{90}$ - may be perceived, and even without publicising its intents its conduct is not the result of a secrecy.

The property legal interest is another item that is directly confronted by cartels. The Competition Committee of OECD came to the conclusion that "[...] the magnitude of harm from cartels is many billions of dollars annually", ${ }^{91}$ and the private enforcement directive established a harm causation presumption only to cartels. ${ }^{92}$ Other competition infringements may also - and normally do - cause harm, namely the abuse of a dominant position, but the reality is that experience and empirical economic analysis clearly indicate that cartels significantly increase prices. ${ }^{93}$ And by doing

“Competition Agency Design: What's on the Menu?", European Competition Journal 8, no. 3 (2012): 527-538; Jeremy Lever and John Pike, "Cartel Agreements, Criminal Conspiracy and the Statutory 'Cartel Offence' - Part 1”, European Competition Law Review 26, no. 2 (2005): 90-97; Jeremy Lever and John Pike, "Cartel Agreements, Criminal Conspiracy and the Statutory 'Cartel Offenc' - Part 2", European Competition Law Review 26, no. 3 (2005); 164-172; Angus Macculloch, "Honesty, Morality and the Cartel Offence", European Competition Law Review 28, no. 6 (2007): 355-363; Macculloch, "The Cartel Offence", 73-93; Ali Nikpay and Deirdre Taylor, "The New UK Competition Regime: Radically Different or More of the Same?", Journal of European Competition Law \& Practice 5, no. 5 (2014): 284-286; Stephan, Four Key Challenges, 1-30; Bruce Wardhaugh, "The Cartel Offence within a 'World Class' Competition Regime: An Assessment of the Bis Consultation Exercise and Its Results", European Competition Journal 8, no. 3 (2012): 573-588; Peter Whelan, "Improving Criminal Cartel Enforcement in the UK: The Case for the Adoption of Bis's 'Option 4'”, European Competition Journal 8, no. 3 (2012): 589-601; and Stephen Wilks, "Institutional Reform and the Enforcement of Competition Policy in the UK", European Competition Journal 7, no. 1 (2011): 1-23.

${ }^{89}$ As Jones and Williams, "The UK Response to the Global Effort against Cartels", 102, refer "Of all agreements, cartels most contradict the principles of the free market economy: the operators specifically conspire to eliminate the free play of competition between themselves".

${ }^{90}$ On the different types of abuse, see Sofia Pais, Entre Inovação e Concorrência - Em Defesa de um Modelo Europeu (Lisboa: Universidade Católica Editora, 2011), 494-497.

${ }^{91}$ OCDE, "Fighting Hard-Core Cartels: Harm, Effective Sanctions and Leniency Programmes" (Paris: OCDE, 2002), 72.

${ }^{92}$ Article 17(2) of Directive 2014/104/EU.

${ }^{93}$ See e.g. Glenn Harrison and Matthew Bell, "Recent Enhancements in Antitrust Criminal Enforcement: Bigger Sticks and Sweeter Carrots", Houston Business and Tax Law Journal (2006): 222. 
so, cartels “[...] 'unfairly' extract wealth from consumers, turning it into monopoly profits". 94

The public or private nature of the harmed patrimony or property is not relevant for justifying its protection as legal interest. Both must equally be safeguarded from "unfair" risks and transactions. The distinction to be made here is that when the object of the cartel is to distort competition in a public procedure or public tender, then the public treasury and/or fiscal assets are affected, with redistribution goals and the allocation of public resources to societal needs to be equally harmed. Hence the distinction, in the sense of even more seriousness, of bid-rigging vis-a-vis hard-core cartels.

\section{Conclusion}

Cartel and bid rigging infringements have distinctive characteristics which put them at a level of seriousness and harm that is far superior to any other competition infringements. We consider that there are grounds to discuss the merits of the legislative decision to establish the same abstract sanctions for all competition infringements, as in EU and Portuguese competition laws.

That conclusion is not solely based on traditional arguments favouring cartel and bid rigging criminalisation. Indeed, the criminalisation argument may be strengthened through the application of common instruments in criminology such as the analysis of the legal interests protected by the norm, revealing that the distinctive features of cartels and bid rigging lie in the extent to which such conducts infringe and harm the entire set of legal interests that are (or may be) defended by competition laws.

\section{Bibliography}

Albuquerque, Pedro de. "Direito Português da Concorrência: Em Torno do DecretoLei N. ${ }^{\circ}$ 422/83". Revista da Ordem dos Advogados 50, no. 3 (1990): 577-669.

Andriychuk, Oles. "Rediscovering the Spirit of Competition: On the Normative Value of the Competitive Process". European Competition Journal 6, no. 3 (2010): 575-610. Baptista Machado, João. Introdução ao Direito e ao Discurso Legitimador. 1986. Reprint, Coimbra: Almedina, 2016.

\footnotetext{
${ }^{94}$ Robert H. Lande, "Wealth Transfers as the Original and Primary Concern of Antitrust: The Efficiency Interpretation Challenged”, Hastings Law Journal 34, no. 1 (1982): 93.
} 
Beaton-Wells, Caron. “Criminalising Cartels: Australia’s Slow Conversion”. World Competition 31, no. 2 (2008): 205-233.

Beaton-Wells, Caron, and Christine Parker. "Justifying Criminal Sanctions for Cartel Conduct: A Hard Case”. Journal of Antitrust Enforcement 1, no. 1 (2013): 198-219.

Beaton-Wells, Caron, and Christine Parker. "Justifying Criminal Sanctions for Cartel Conduct: A Hard Case”. Journal of Antitrust Enforcement (2012): 1-22.

Blaise, Jean-Bernard. "La Sanction Pénale - Colloque Les Sanctions du Droit de la Concurrence". Concurrences, Revue des Droits de la Concurrence 1-2013 (2013): 23-26.

Bork, Robert H. "Contrasts in Antitrust Theory: I”. Columbia Law Review 65, no. 3 (1965): 401-416.

Bork, Robert H. "Vertical Restraints: Schwinn Overruled”. The Supreme Court Review (1977): 171-192.

Bright, Christopher. "EU Competition Policy: Rules, Objectives and Deregulation”. Oxford Journal of Legal Studies 16, no. 4 (1996): 535.

Brisimi, Vasiliki, and Maria Ionnidou. "Criminalizing Cartels in Greece: A Tale of Hasty Developments and Shaky Grounds". World Competition 34, no. 1 (2011): 157-176.

Buxbaum, Hannah L. "German Legal Culture and the Globalisation of Competition Law: A Historical Perspective on the Expansion of Private Antitrust Enforcement". Berkeley Journal of International Law 23, no. 2 (2005): 101-122.

Caeiro, Pedro. "Perspectivas de Formação de um Direito Penal da União Europeia". In Direito Penal Económico e Europeu: Textos Doutrinários, 519-532. Coimbra: Coimbra Editora, 1998.

Caspari, Manfred. "1992 - EEC Competition Law and Industrial Policy”. Fordham Corp. L. Inst. 1989 (B. Hawk, org., 1990) (1990): 163-180.

Castillo de La Torre, Fernando. "Evidence, Proof and Judicial Review in Cartel Cases". World Competition 32, no. 4 (2009): 505-578.

Cayseele, Patrick Van, and Roger J. Van den Bergh. “Antitrust Law”. In Encyclopedia of Law and Economics, edited by Boudewijn Bouckaert and Gerrit de Geest, 467-497. Cheltenham: Edward Elgar Publ., 2000.

Collins, Paul, and Vicky Eatrides. "An Analysis of the Proposal to Decriminalise the Anti-Competitive Pricing Practices under the Competition Act". World Competition 26, no. 3 (2003): 381-432.

Combe, Emmanuel. "Quelles Sanctions Contre les Cartels? Une Perspective Économique”. Revue internationale de droit économique 26, no. 1 (2006): 9-44.

Combe, Emmanuel, and Constance Monnier. "Fines Against Hard Core Cartels in Europe: The Myth of Overenforcement”. Antitrust Bulletin 56, no. 2 (2011): 235. 
Connor, John M. "Global Cartels Redux: The Amino Acid Lysine Antitrust Litigation (1996)". In The Antitrust Revolution - Economics, Competition and Policy, edited by John E. Kwoka, Jr. and Lawrence J. White, 252-276. Nova Iorque: Oxford University Press, 2004.

Connor, John M., and Robert H. Lande. "How High Do Cartels Raise Prices? Implications for Optimal Cartel Fines". Tulane Law Review 80 (2005): 513.

Cooper, James C., Luke Froeb, Daniel P. O’Brien, and Michael Vita. “A Comparative Study of United States and European Union Approaches to Vertical Policy". George Mason Law Review 13, no. 2 (2005): 297-303.

Crampton, Paul, and Brian A. Facey. "Revisiting Regulation and Deregulation Through the Lens of Competition Policy. Getting the Balance Right". World Competition 25, no. 1 (2002): 25-53.

Crane, Daniel A. “Technocracy and Antitrust”. Texas Law Review 86 (2007): 1159.

Feijoo Sánchez, Bernardo. "Sobre la Crisis de la Teoría del Bien Jurídico”. Indret: Revista para el Análisis del Derecho, no. 2 (2008): 1-16.

Figueiredo Dias, Jorge de. Direito Penal - Parte Geral - Tomo I - Questões Fundamentais. A Doutrina Geral Do Crime. Coimbra: Coimbra Editora, 2004.

First, Harry. “The Case for Antitrust Civil Penalties”. Antitrust Law Journal 76, no. 1 (2009): 127.

Fox, Eleanor M. “The Modernisation of Antitrust: A New Equilibrium”. Cornell Law Review 66, no. 6 (1981): 1140.

Freeman, Peter. "'Beware the Ides of March' - the Government's Proposed Competition Reforms”. European Competition Journal 8, no. 3 (2012): 563-572.

Freeman, Peter. "The Competition and Markets Authority: Can the Whole Be Greater Than the Sum of Its Parts?". Journal of Antitrust Enforcement 1, no. 1 (2013): 4-23.

Gal, Michal S. "Free Movement of Judgments: Increasing Deterrence of International Cartels through Jurisdictional Reliance". Virginia Journal of International Law 51, no. 1 (2010): 57.

Gal, Michal S. "Monopoly Pricing as an Antitrust Offense in the U.S. and the EC: Two Systems of Belief About Monopoly". The Antitrust Bulletin Spring-Summer (2004): 343-384.

Gerber, David J. "Competition Law and the WTO: Rethinking the Relationship". Journal of International Economic Law 10, no. 3 (2007): 707-24.

Gerber, David J. "Modernising European Competition Law: A Developmental Perspective". European Competition Law Review 22, no. 4 (2001): 122-30.

Gerber, David J. “The Transformation of European Community Competition Law”. Harvard International Law Journal 35, no. 1 (1994): 97-147. 
Gifford, Daniel J., and Robert T. Kudrle. "European Union Competition Law and Policy: How Much Latitude for Convergence with the United States?”. Antitrust Bulletin 48, no. 2 (2003): 727-780.

Ginsburg, Douglas H., and Joshua D. Wright. "Antitrust Sanctions”. Competition Policy International 6, no. 2 (2010): 3-39.

Graham, Cosmo. "The Reform of UK Competition Policy". European Competition Journal 8, no. 3 (2012): 539-562.

Gray, Anthony. "Criminal Sanctions for Cartel Behaviour". Queensland University of Technology Law and Justice Journal 8, no. 2 (2008): 364-379.

Guerrin, Maurice, and Georgios Kyriazis. "Cartels: Proof and Procedural Issues". Fordham Corp. L. Inst. 1992 (B. Hawk, org., 1993) (1993): 773-843.

Harding, Christopher. "Cartel Deterrence: The Search for Evidence and Argument". Antitrust Bulletin 56, no. 2 (2011): 345.

Hargita, Árpád, and Tihamér Tóth. "God Forbid Bid-Riggers: Developments under the Hungarian Competition Act”. World Competition 28, no. 2 (2005): 205-231.

Harrison, Glenn, and Matthew Bell. "Recent Enhancements in Antitrust Criminal Enforcement: Bigger Sticks and Sweeter Carrots". Houston Business and Tax Law Journal (2006): 207-240.

Hawk, Barry E. "La Révolution Antitrust Américaine: Une Leçon pour la Communauté Économique Européenne?”. Revue Trimestrielle de Droit Européen 25, no. 1 (1989): 5-44.

Hüschelrath, Kai, Nina Leheyda, and Patrick Beschorner. “The Deterrent Effect of Antitrust Sanctions: Evidence from Switzerland”. Antitrust Bulletin 56, no. 2 (2011): 427. ICN. “Defining Hard Core Cartel Conduct”. Luxembourg: ICN, 2005.

Jenny, Frédéric. "L'Articulation des Sanctions en Matière de Droit de la Concurrence du Point de Vue Économique - Colloque Les Sanctions du Droit de la Concurrence". Concurrences, Revue des Droits de la Concurrence 1-2013 (2013): 1-11.

Jones, Alison. "Analysis of Agreements under U.S. and EC Antitrust Law - Convergence or Divergence? ". Antitrust Bull. 51, no. 4 (2006): 691.

Jones, Alison, and Rebecca Williams. "The UK Response to the Global Effort against Cartels: Is Criminalisation Really the Solution?". Journal of Antitrust Enforcement 2, no. 1 (2014): 100-125.

Joshua, Julian M. “The UK's New Cartel Offence and its Implications for EC Competition Law: A Tangled Web”. European Law Review 28, no. 5 (2003): 620-641. Joshua, Julian M., Peter D. Camesasca, and Youngjin Jung. "Extradition and Mutual Legal Assistance Treaties: Cartel Enforcement's Global Reach”. Antitrust Law Journal 75, no. 2 (2008): 353-397. 
Khan, Aaron. "Rethinking Sanctions for Breaching EU Competition Law: Is Director Disqualification the Answer?". World Competition 35, no. 1 (2012): 77-102.

Koch, Fritz E. "Cartels as Instruments of International Economic Organisation. Public and Private Legal Aspects of International Cartels". Modern Law Review 8, no. 3 (1945): 130-148.

Kokkoris, Ioannis. "Should Crisis Cartels Exist amid Crises?". Antitrust Bulletin 55, no. 4 (2010): 727.

Kolasky, William J. "Criminalizing Cartel Activity: Lessons from the U.S. Experience”. In 5e GCLC Lunch Talk: International Cartel Enforcement. Bruxelas: Collège d'Europe, 2004.

Kovacic, William E. "An Integrated Competition Policy to Deter and Defeat Cartels". Antitrust Bulletin 51, no. 4 (2006): 813.

Kovacic, William E., and David A. Hyman. "Competition Agency Design: What's on the Menu?”. European Competition Journal 8, no. 3 (2012): 527-538.

Kroes, Neelie. “Competition Policy and the Crisis - the Commission's Approach to Banking and Beyond". Antitrust Bulletin 55, no. 4 (2010): 715.

Kronstein, Heinrich. "The Dynamics of German Cartels and Patents. I”. University of Chicago Law Review 9, no. 4 (1942): 643-671.

Lande, Robert H. "Wealth Transfers as the Original and Primary Concern of Antitrust: The Efficiency Interpretation Challenged”. Hastings Law Journal 34, no. 1 (1982): 65.

Leibenstein, Harvey. "Allocative Efficiency Vs. 'X-Efficiency". American Economic Review 56, no. 3 (1966): 392-415.

Lenaerts, Koen, and Piet Van Nuffel. Constitutional Law of the European Union. London: Sweet \& Maxwell, 1999.

Leslie, Christopher R. “Antitrust Damages and Deadweight Loss”. Antitrust Bulletin 51, no. 3 (2006): 521.

Lever, Jeremy, and John Pike. "Cartel Agreements, Criminal Conspiracy and the Statutory 'Cartel Offence' - Part 1'. European Competition Law Review 26, no. 2 (2005): 90-97.

Lever, Jeremy, and John Pike. "Cartel Agreements, Criminal Conspiracy and the Statutory 'Cartel Offence' - Part 2". European Competition Law Review 26, no. 3 (2005): 164-172.

Louis, Fréderic, and Gabriele Accardo. "Ne Bis in Idem, Part 'Bis". World Competition 34, no. 1 (2011): 97-112.

Lowe, Philip, and Ansgar Held. "Modernisation and Beyond: The Role of Competition Policy in Driving Economic Growth”. European Competition Journal 1, no. 1 (2005): 35. Macculloch, Angus. "Honesty, Morality and the Cartel Offence". European Competition Law Review 28, no. 6 (2007): 355-363. 
Macculloch, Angus. “The Cartel Offence: Defining an Appropriate 'Moral Space”. European Competition Journal 8, no. 1 (2012): 73-93.

Marshall, Brenda. "Criminalisation of Cartel Conduct: Compelling Compliance with Anti-Collusion Laws". Journal of the Australasian Law Teachers Association, no. 3 (2010): 11-18.

Monti, Giorgio. "Article 81 EC and Public Policy". Common Market Law Review 39, no. 5 (2002): 1057.

Mortelmans, Kamiel J. M. “Towards Convergence in the Application of the Rules on Free Movement and Competition?". Common Market Law Review 38, no. 3 (2001): 613-649.

Motta, Massimo. Competition Policy: Theory and Practice. Cambridge: Cambridge University Press, 2004.

Moura e Silva, Miguel. “As Práticas Restritivas da Concorrência na Lei N. ${ }^{\circ}$ 19/2012 - Novos Desenvolvimentos". In O Novo Regime Jurídico da Concorrência. Universidade Católica Portuguesa - Lisboa: Autoridade da Concorrência, 2012.

Murphy, Gavin. "Fine and Prohibition Order in Canadian Bid-Rigging Case Involving Government Contracts”. European Competition Law Review 31, no. 1 (2010): 21-25.

Nagy, Csongor Istvan. "The Constitutional Court Condemned Hungarian Statute Imposing 'Occupational Ban' on Executives of Cartelist Companies”. European Competition Law Review 30, no. 8 (2009): 371-372.

Nazzini, Renato. "Fundamental Rights beyond Legal Positivism: Rethinking the Ne Bis in Idem Principle in EU Competition Law". Journal of Antitrust Enforcement (2014): 1-35.

Nikpay, Ali, and Deirdre Taylor. "The New UK Competition Regime: Radically Different or More of the Same?". Journal of European Competition Law \& Practice 5, no. 5 (2014): 278-286.

Norgren, Claes. "Criminal Enforcement of Antitrust Laws". In Fordham Law Seminar. New York, 2006.

O’Kane, Michael. "Does Prison Work for Cartelists? The View from Behind Bars: An Interview of Bryan Allison”. Antitrust Bulletin 56, no. 2 (2011): 483.

OCDE. "Fighting Hard-Core Cartels: Harm, Effective Sanctions and Leniency Programmes". Paris: OCDE, 2002.

OCDE. "Recommendation of the Council Concerning Effective Action against Hard Core Cartels”. Paris: OCDE, 1998.

Odudu, Okeoghene. "The Wider Concerns of Competition Law". Oxford Journal of Legal Studies 30, no. 3 (2010): 599-613.

Pais, Sofia Oliveira. Entre Inovação e Concorrência - Em Defesa de um Modelo Europeu. Lisboa: Universidade Católica Editora, 2011. 
Pappalardo, Aurelio. "Les Relations entre le Droit Communautaire et les Droits Nationaux de la Concurrence". Revue Internationale de Droit Économique 9, no. 1 (1995): 123-160.

Parret, Laura. “Shouldn't We Know What We Are Protecting? Yes We Should! A Plea for a Solid and Comprehensive Debate about the Objectives of EU Competition Law and Policy”. European Competition Journal 6, no. 2 (2010): 339-376.

Pera, Alberto. "Changing Views of Competition, Economic Analysis and EC Antitrust Law”. European Competition Journal 4, no. 1 (2008): 127-168.

Posner, Richard A. Antitrust Law - an Economic Perspective. $2^{\text {nd }}$ ed. Chicago: Chicago Univ. Press, 2001.

Riley, Alan. "The Modernisation of EU Anti-Cartel Enforcement: Will the Commission Grasp the Opportunity?". European Competition Law Review 31, no. 5 (2010): 191-207.

Rossi, Guido. “Antitrust e Teoria della Giustizia”. Rivista delle Società 40, no. 1 (1995): $1-21$.

Roxin, Claus. "O Conceito de Bem Jurídico como Padrão Crítico da Norma Penal Posto à Prova”. Revista Portuguesa de Ciência Criminal 23, no. 1 (2013): 7-43.

Schinkel, Maarten Pieter. "Effective Cartel Enforcement in Europe". World Competition 30, no. 4 (2007): 539.

Schoneveld, Frank R. "Cartel Sanctions and International Competition Policy: CrossBorder Cooperation and Appropriate Forums for Cooperation”. World Economy 26, no. 3 (2003): 433-471.

Schwarze, Jürgen. "Les Sanctions Imposées pour les Infractions ou Droit Européen de la Concurrence Selon l'Article 23 du Règlement No 1/2003 CE à la Lumière des Principes Généraux du Droit”. Revue Trimestrielle de Droit Européen 43, no. 1 (2007): 1-24.

Shaffer, Gregory C., and Nathaniel H. Nesbitt. "Criminalizing Cartels: A Global Trend?" Legal Studies Research Paper Series (2011).

Silva, Fátima Reis. "Um Olhar 'Comercial' Sobre o Direito Contra-Ordenacional”. Julgar, no. 8 (2009): 101-117.

Silva Pereira, Maria Margarida. "Bens Jurídicos Colectivos e Bens Jurídicos Políticos". In Liber Discipulorum para Jorge de Figueiredo Dias, edited by Manuel da Costa Andrade, José de Faria Costa, Anabela Miranda Rodrigues and Maria João Antunes, 293-316. Coimbra: Coimbra Editora, 2003.

Smith, Adam. A Riqueza das Nações. Translated by Alexandre Amaral Rodrigues and Eunice Ostrensky. São Paulo: Livraria Martins Fontes, 2003.

Smith, Rhonda L., and Stephen King. "Does Competition Law Adequately Protect Consumers?". European Competition Law Review 28, no. 7 (2007): 412. 
Stephan, Andreas. "Four Key Challenges to the Successful Criminalisation of Cartel Laws". Journal of Antitrust Enforcement (2014): 1-30.

Stephan, Andreas. "Price Fixing in Crisis: Implications of an Economic Downturn for Cartels and Enforcement". World Competition 35, no. 3 (2012): 511-528.

Stigler, George J. “The Xistence of X-Efficiency”. American Economic Review 66, no. 1 (1976): 213-216.

Sullivan, E. Thomas, and Wolfgang Fikentscher. "On the Growth of the Antitrust Idea”. Berkeley Journal of International Law 16 (1998): 197-233.

Taipa de Carvalho, Américo A. Direito Penal - Parte Geral. Questões Fundamentais. Porto: Publicações Universidade Católica, 2003.

Takigawa, Toshiaki. "Harmonisation of Competition Laws after Doha Substantive and Procedural Harmonisation”. Journal of World Trade 36, no. 6 (2002): 1111-1124.

Varney, Christine A. "Striving for the Optimal Balance in Antitrust Enforcement: Single-Firm Conduct, Antitrust Remedies, and Procedural Fairness". Paper presented at the Council on Foreign Relations, 8.10.2009, New York, 2009.

Victor, A. Paul. “The Growth of International Criminal Antitrust Enforcement”. George Mason Law Review 6, no. 3 (1998): 493-503.

Viros, David. "Individual Criminal Sanctions in France - Individual Sanctions for Competition Law Infringements: Pros, Cons and Challenges". Concurrences, Revue des Droits de la Concurrence 2-2016 (2016): 24-27. https://papers.ssrn.com/sol3/ papers2.cfm?abstract_id=2782090.

Wagner-Von Papp, Florian. "Criminal Antitrust Law Enforcement in Germany: 'The Whole Point Is Lost If You Keep It a Secret! Why Didn't You Tell the World, Eh?'”. (2010). Published electronically 5 Apr 2010. http://ssrn.com/abstract=1584887.

Wagner-Von Papp, Florian. "Introduction - Individual Sanctions for Competition Law Infringements: Pros, Cons and Challenges". Concurrences, Revue des Droits de la Concurrence 2-2016 (2016): 14-23. https://papers.ssrn.com/sol3/papers2. cfm?abstract_id=2782090.

Wallace, Cynthia Day. “'Extraterritorial' Discovery: Ongoing Challenges for Antitrust Litigation in an Environment of Global Investment". Journal of International Economic Law 5, no. 2 (2002): 353-392.

Waller, Spencer Weber. "Public Choice Theory and the International Harmonisation of Antitrust Law”. Antitrust Bulletin 48, no. 2 (2003): 427-438.

Wardhaugh, Bruce. "The Cartel Offence within a 'World Class' Competition Regime: An Assessment of the Bis Consultation Exercise and Its Results". European Competition Journal 8, no. 3 (2012): 573-588.

Werden, Gregory J. "Sanctioning Cartel Activity: Let the Punishment Fit the Crime". European Competition Journal 5, no. 1 (2009): 19-36. 
Werden, Gregory J., Scott D. Hammond, and Belinda A. Barnett. "Deterrence and Detection of Cartels: Using All the Tools and Sanctions". Antitrust Bulletin 56, no. 2 (2011): 207-234.

Whelan, Peter. "A Principled Argument for Personal Criminal Sanctions As Punishment under EC Cartel Law". The Competition Law Review 4, no. 1 (2007): 7-40.

Whelan, Peter. "Improving Criminal Cartel Enforcement in the UK: The Case for the Adoption of Bis's 'Option 4'”. European Competition Journal 8, no. 3 (2012): 589-601.

Whelan, Peter. The Criminalisation of European Cartel Enforcement - Theoretical, Legal, and Practical Challenges. Oxford Studies in European Law. Edited by Paul Craig and Gráinne de Búrca. NY: Oxford University Press, 2014.

Wilks, Stephen. "Institutional Reform and the Enforcement of Competition Policy in the UK”. European Competition Journal 7, no. 1 (2011): 1-23.

Wils, Wouter P. J. "Antitrust Compliance Programmes and Optimal Antitrust Enforcement". Journal of Antitrust Enforcement 1, no. 1 (2013): 52-81.

Wils, Wouter P. J. "Is Criminalisation of EU Competition Law the Answer?". World Competition 28, no. 2 (2005): 117-159.

Wils, Wouter P. J. "Leniency in Antitrust Enforcement: Theory and Practice". World Competition 30, no. 1 (2007): 25.

Wils, Wouter P. J. "The Principle of Ne Bis in Idem in EC Antitrust Enforcement: A Legal and Economic Analysis". World Competition 26, no. 2 (2003): 131-148.

Witt, Anne C. "Public Policy Goals under EU Competition Law - Now Is the Time to Set the House in Order". European Competition Journal 8, no. 3 (2012): 443-71.

Zimmer, Daniel. "Individual Sanctions in German Competition Law: The Case for a Criminalisation of Antitrust Offences? - Individual Sanctions for Competition Law Infringements: Pros, Cons and Challenges". Concurrences, Revue des Droits de la Concurrence 2-2016 (2016): 28-32. https://papers.ssrn.com/sol3/papers2. cfm?abstract_id=2782090. 